\title{
Understanding the Benefit Sought by Rural Tourists and Accommodation Preferences:
}

\section{A South Korea Case}

\begin{abstract}
Rural tourism has been widely acknowledged for its effectiveness in contributing to rural areas' development. With strong government support, rural tourism has developed in many countries during the last several decades. This study aims to improve the understanding regarding tourism in Korean rural areas using a segmentation approach. The responses of 442 tourists in 23 rural villages were analyzed. Four segments of tourists were identified based on the different benefits they sought for their vacation in rural establishments. The estimation of a $\underline{m M u l t i n o m i a l ~} \underline{\text { LLogit }} \underline{\mathrm{mM} M o d e l}$ determined the socio-demographic characteristics and the preferred accommodations of a rural tourist. Discussions and implications of the detailed findings are provided in the last section.
\end{abstract}




\section{INTRODUCTION}

Rural tourism has been growing rapidly worldwide and has attracted increased attention from marketers and scholars (Oppermann, 1996; Canoves, Herrera, \&and Villarino, 2005; Busby \&and Rendle, 2000). A leading reason for its popularity is its demonstrated effectiveness in developing rural areas (Fleischer \&and Tchetchick, 2005; Fleischer \&and Felsenstein, 2000; Echtner, 1995; Canoves, Villarino, Priestley, \&and Blanco, 2004; Liu, 2006; Sharpley, 2002). For several decades, the proliferation of rural tourism studies has focused on parts of Europe, such as France, the United Kingdom (UK), Germany, the Netherlands, and Spain (Canoves et al. 2004; Molera \&and Albaladejo, 2007). Since the 1960s, European governments have acknowledged rural tourism as a powerful strategy for developing and diversifying economic activities in rural areas. As a result, rural tourism in those countries has evolved over several decades with strong governmental support. As Canoves et al. (2004) highlighted, rural tourism in European countries is in 'a third phase, the maturity of rural tourism' (p.759). However, the situation seems to be different in other countries, particularly in Asian countries, including China, Malaysia, and South Korea, where rural tourism is taking its first steps (Liu, 2006; Ying \&and Zhou, 2007; Su, 2011; Park \&and Yoon, 2009). Rural tourists' demands and characteristics in Asian countries are expected to differ notably from those in European countries. However, there has been surprisingly little attention paid to rural tourism in the Asian tourist context.

To fill this gap, this study focuses on rural tourism in South Korea, one of the Asian countries where rural tourism is in an _-introductory stage?'- (Park \&and Yoon, 2009, p.107). In South Korea, rural tourism has a short history; however, it is expanding rapidly due to strong support from the Korean government (Park \&and Yoon, 2009; Yoon, 2008). Along with higher income levels and the implementation of the five-day workweek, Koreans 
become more interested in leisure activities than ever before. To respond to this growing demand, the Korean government has played a leading role in the development of rural tourism, successfully launching two major projects, including the Rural Traditional Theme Village (RTTV) and the Green Rural Experience Village (GREV) (Rural Development Administration, 2009). Various types of accommodations, known as 'rural houses', have been restored or newly constructed using traditional materials, including hostels, campsites, rented houses, and rural houses in different regions. However, there has been lack of research regarding the accommodation preferences and benefits sought by Korean rural tourists. It is critical for tourism marketers and the Korean government to understand 'what types' of accommodations are preferred and the reasons for which the accommodation style is preferred. By having a better insight into Korean rural tourists, tourism marketers are able to provide tourists with tourism products that can satisfy their demands, including rural accommodations.

This study provides marketers with important information through a benefit market segmentation approach, profiling the characteristics of each segment by focusing on its accommodation preferences. A segmentation approach has been widely supported as a tool for gaining deeper insights into markets and developing marketing strategies (Lee, Lee, Bernhard, \&and Yoon, 2006; Bowen, 1998; Park \&and Yoon, 2009; Woodside \&and Jacobs, 1985). Although previous studies on rural tourism have demonstrated different segments in various countries (Barke, 2004; Frochot, 2005; Kastenholz, Davis, \&and Paul, 1999; Molera \&and Albaladejo, 2007; Roberts \&and Hall, 2001), one should be cautious when applying the findings focusing on places where rural tourism had been evolving for several decades. This paper's primary contribution is its empirical study of rural tourists in South Korea, where rural tourism is in its beginning stages. By employing a segmentation approach, this study is expected to improve the understanding of rural tourism in South Korea. 


\section{Background of Rural Tourism}

The term 'rural tourism' has been referred to in numerous ways in previous studies, ranging from 'non-urban tourism’ (Oppermann, 1996), 'farm tourism' (Nilsson, 2002; Flesher \&and Tchetchik, 2005), to ‘cultural tourism’ (MacDonald \&and Jolliffe, 2003; Butler \&and Hall, 1998). It has been suggested that 'rural tourism' should be understood as a broader concept as it includes not only 'farm tourism' but also non-farm tourism in rural areas (Oppermann, 1996; Nilsson, 2002). Moreover, in recent years, researchers have paid more attention to 'cultural elements' in understanding rural tourists, as tourists visit rural destinations for historic heritage and cultural elements as well as for enjoying the natural environment (MacDonald \&and Jolliffe, 2003; Ying \&and Zhou, 2007; Panyik, Costa, \&and Ratz, Farmara, 2011). Considering these ideas, rural tourism should be understood in a broad way as it providesing tourists not only with the 'natural environment' but also with the 'culture' of the rural areas. Accordingly, this study defines 'rural tourists' as 'those who visit Formatted: Font: Italic rural areas, including farms, who are attracted by not only 'rural environmental settings' but also by 'cultural experiences'.

Rural tourism has been considered beneficial for the host community (the economic and social dimensions), the land itself (environmental maintenance), and tourists (leisure and tourism in the countryside) (Canoves et al., 2004). Most countries have encouraged rural tourism to positively impact rural economic development (Fleisher \&and Flesenstein, 2000; Fleisher \&and Tchetchik, 2005; Fleischer \&and Pizam, 1997; Busby \&and Rendle, 2000; Canoves et al. 2004; Echtner, 1995). Because rural tourism is characterized by small and; family-centered enterprises, public support is crucial to its success (Fleischer \&and Pizam, 1997; Fleisher \&and Flesenstein, 2000; Getz \&and Carlsen, 2000). Thus, to be successful, the development of rural areas should be approached cautiously and in cooperation with local 
communities (Wilson, Fesenmaier, Fesenmaier, and Van Es, et al. 2001). Moreover, Aa profound knowledge of the local capacity and cultural adaptability of rural areas is essential to prevent 'damaged environments and corrupt local cultures resulting from ill-advised tourism promotion’.(Fleischer \&and Flesenstein, 2000, p.1024).

Rural tourists have various needs and wants (Frochot, 2005; Molera and Albaladejo, 2007). $\underline{\text { Rural tourists vary in terms of the benefits they seek, some of which are cultural experiences, }}$ sports, rural activities, and tranquility (Kastenholz, Davis, and Paul, 1999; Frochot, 2005; Molera and Albaladejo, 2007). Therefore, market segmentation can be useful for gaining deeper insights into customers' desires and for developing marketing strategies (Lee, Lee, Bernhard, and Yoon, 2006; Bowen, 1998; Park and Yoon, 2009; Woodside and Jacobs, 1985).

Previous studies have indicated that rural tourists are heterogeneous, having different needs and desires (Barke, 2004; Frochot, 2005; Molera \& Albaladejo, 2007). Some tourists may wish to enjoy 'tranquility', while others may desire to experience various rural activities and eultural experiences (Kastenholz et al. 1999; Molera \& Albaladejo, 2007). Thus, market segmentation has been employed to gather deeper insights into customers' needs and wants and to develop marketing strategies (Lee et al. 2006; Bowen, 1998; Park \& Yoon, 2009; Woodside \& Jacobs, 1985). For example, in the Portuguese context, Kastenholz et al. (1999) identified four segments: 'want-it-all rural tourists,' 'independent rural tourists,' 'environmental rumal tourists,' and 'traditional rural tourists'. In a similar way, Frochot (2005) identified four segments in the context of Scotland: 'active tourists,' 'relaxers,' 'gazers,' and 'rurals'. Frochot's (2005) 'rurals' and Kastenholz et al.'s (1999) 'traditional rural tourists' appear to be similar in terms of the tourists' interests (rural life) and priorities, while 'active tourists' and 'want it all rural tourists' are comparable because they are interested in experiencing various rural activities. Meanwhile, Frochot (2005) identified the 'familyoriented tourists' who placed their highest value on spending time with their children. In a
Formatted: Font color: Text 1

Formatted: Font: Italic, Font color: Text 1

Formatted: Font color: Text 1 
later study, Molera \& Albaladejo (2007) supported the notion of 'family-oriented tourists' in Frocho's (2005) study by empirically identifying 'rural family tourists' in Spain along with 'relaxed rural tourists,' 'active rural tourists,' 'rural life tourists,' and 'tourists of rural accommodations'.

Although most of studies on rural tourism have been limited to countries where the industry is already mature, there have been several investigations of rural tourism in the South Korean context. Lee, Park, \& Yoon (2006) identified five segments of rural tourists in South Korea, which include 'passive tourists', 'rural-centric tourists,' 'want it all tourists,' 'souvenir seekers,' and 'novelty seekers.' In their subsequent study, Park \& Yoon (2009) identified four segments, including 'family-togetherness tourists,' 'passive tourists,' 'want-itall tourists,' and 'seeking learning and excitement tourists.' According to a closer analysis of the various segments, it should be noted that there are some similarities and differences with respect to the segments that have been identified in previous studies. For example, the 'family togetherness tourists' in Park \& Yoon's (2009) study appear to be similar to 'family oriented tourists' in Frochot's (2005) and Molera \& Albaladejo's (2007) study, and 'want-it-all tourists' are similar to the segment identified in Devesa, Laguna \& Palacios (2010) and Kastenholz et al.'s (1999) study in the European context. Meanwhile, some segments, such as 'souvenir seekers', seem to be a specific segment that can be identified in South Korea.

Rural tourists are attracted to farms, natural environments, adventurous experiences, and Formatted: Indent: First line: $2 \mathrm{ch}$ educational and heritage sites (MacDonald \&and Jolliffe, 2003; Oppermann, 1996). When we review the segments designated by previous studies, tourists seem to have different interests within the 'rural environment' itself; some tourists showed a greater interest in 'rural environments' than others. In this context, the preference for different accommodation types is expected to differ according to different segments. In previous studies, tourists' preferences for certain accommodation types were found to be related to the extent to which the tourists 
desire to experience the local culture during their travels (Weaver, 1991; Basala \&and Klenosky, 2001). Those who wish to relax were likely to prefer large-scale resorts and chain hotels, while those who desire to experience local cultures showed a greater preference for small and locally owned accommodations (Basala \&and Klenosky, 2001). According to Albaladejo-Pina \&and Díiaz-Delfa (2005), different demands for accommodation were identified in the rural tourism context: large establishments (large resorts with sports facilities); moderate accommodations (open country or mountain lodging rented directly from the owner); accommodations architecturally reflective of the area located near a town; traditional two- or three-bedroom houses; and former mill houses that rent individual rooms. As observed, a variety of accommodations are available, ranging from self-catered lodging and bed $\underline{\&} \&$ breakfasts to corporate hotels or resorts in rural areas (Morrison, Pearce, Moscardo, Nadkarni \&and O’Leary, 1996; Oppermann, 1996). Thus, it is critical for marketers to understand the tourist demand for rural accommodations. However, as prior literature on rural tourism has been limited to Europe, little is known regarding the benefits and accommodation preferences sought by rural tourists from non-Western cultures. Therefore, further studies are needed for an improved understanding of rural tourists from various cultures.

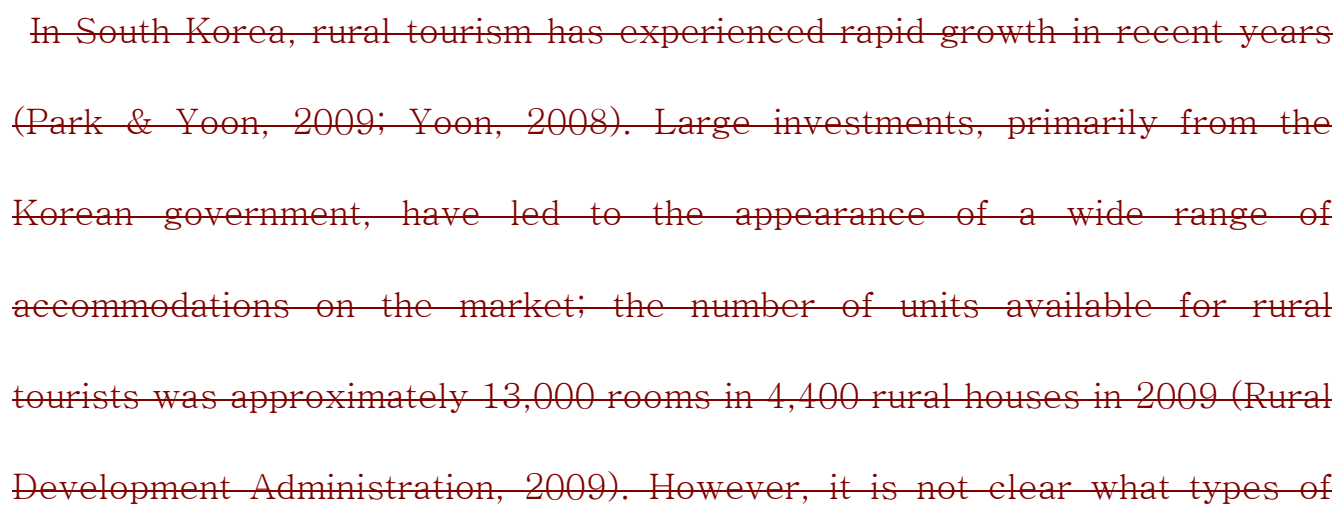




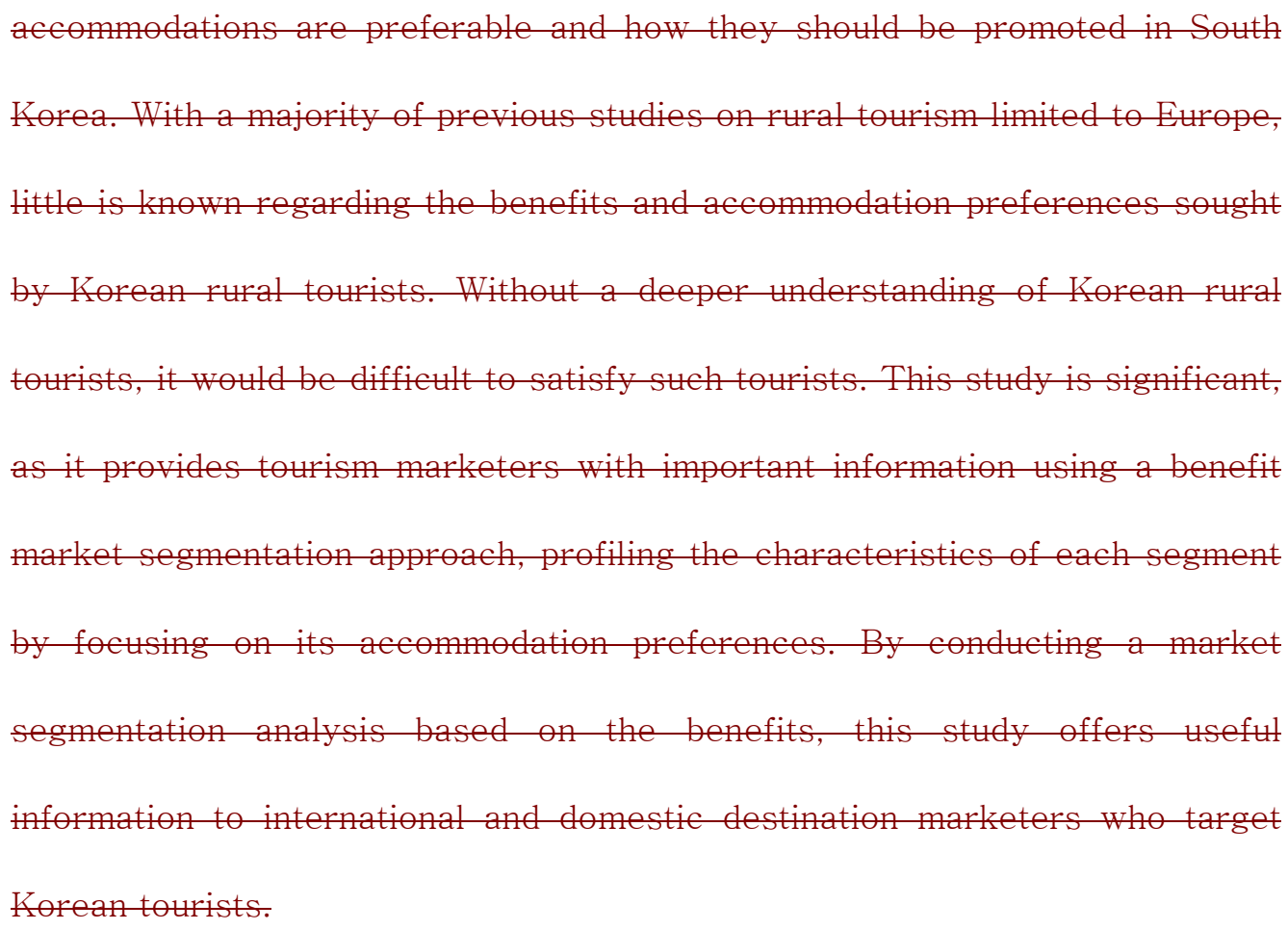

\section{Segmentation of Rural Tourists}

Previous studies have indicated that rural tourists are heterogeneous, having different needs and desires (Barke, 2004; Frochot, 2005; Molera and Albaladejo, 2007). Some tourists may wish to enjoy 'tranquility', while others may desire to experience various rural activities and cultural experiences (Kastenholz et al., 1999; Molera and Albaladejo, 2007). Market segmentation has been employed to gather deeper insights into customers' needs and wants and to develop marketing strategies (Lee et al., 2006; Bowen, 1998; Park and Yoon, 2009; Woodside and Jacobs, 1985). For example, in the Portuguese context, Kastenholz et al. (1999) identified four segments: 'want-it-all rural tourists,' 'independent rural tourists,' 'environmental rural tourists,' and 'traditional rural tourists'. In a similar way, Frochot (2005) $\underline{\text { identified four segments in the context of Scotland: 'active tourists,' 'relaxers,' 'gazers,' and }}$ 
'rurals'. Frochot’s (2005) 'rurals' and Kastenholz et al.'s (1999) 'traditional rural tourists' appear to be similar in terms of the tourists' interests in rural life and priorities, while 'active tourists' and 'want-it-all rural tourists' are comparable because they are interested in experiencing various rural activities. Frochot's (2005) 'family-oriented tourists', those who place their highest values on spending time with their children, were found in Molera and Albaladejo's (2007) study. They supported the significance of 'family-oriented tourists' by empirically identifying this segment in the Spain context. In their study, other segments include 'relaxed rural tourists,' 'active rural tourists,' 'rural life tourists,' and 'tourists of rural accommodations.' Meanwhile, Previous studies have indicated that rural tourists are heterogeneous, with various needs and wants (Barke, 2004; Frochot, 2005; Molera \& Albaladejo, 2007). Market segmentation is useful for gaining deeper insights into customers' desires and for developing marketing strategies (Lee, Lee, Bernhard, \& Yoon, 2006; Bowen, 1998; Park \& Yoon, 2009; Woodside \& Jacobs, 1985). Rural tourists vary in terms of the benefits they seek, some of which are cultural experiences, sports, rural activities, and tranquility (Kastenholz, Davis, \& Paul, 1999; Frochot, 2005; Molera \& Albaladejo, 2007). Previous research on benefit segmentation has primarily studied Europe (Kastenholz, Davis, \& Paul, 1999; Frochot, 2005; Devesa, Laguna \& Palacios, 2010; Molera \& Albaladejo, 2007). For example, Kastenholz, Davis, \& Paul (1999) identified four segments in Portugal: 'wantit all rural tourists,' 'independent rural tourists,' 'environmental rural tourists,' and straditional rural tourists.

Frochot (2005) identified similar segments in Scotland: 'active tourist,' 'relaxers,' ‘gazers,' and 'rurals'. Molera \& Albaladejo (2007) identified five segments in Spain: 'family rural tourists,' 'relaxation rural tourists,' 'active rural tourists,' 'rural life tourists,' and 'tourists of rural accommodations'. Similar to Frochot's (2005) 'gazer,' 'family-oriented tourists' most highly values spending time with their children. Devesa, Laguna \&and Palacios 
(2010) identified slightly different four-segments in Spain: 'culture-seeking visitors,' 'return tourists,' 'gastronomic and nature visitors,' and 'nature and tranquility visitors'. In their study, However, certain segments, such as 'gastronomic and nature visitors' appear to differ from traditional rural tourists that have been identified in other studies.

, differed slightly from those identified in previous studies.

Rural tourism research has been limited to Europe, where rural tourism is already in a mature stage. Although most of studies on rural tourism have been limited to countries where the industry is already mature, there have been several investigations of rural tourism in the South Korean context. Lee, Park, and Yoon (2006) identified five segments of rural tourists in South Korea, which are 'passive tourists,' 'rural-centric tourists,' 'want-it-all tourists,' 'souvenir seekers,' and 'novelty seekers.' In their subsequent study, Park and Yoon (2009) identified four segments; these are 'family-togetherness tourists,' 'passive tourists,' 'want-itall tourists,' and 'seeking learning and excitement tourists.' According to a closer analysis of the various segments, it should be noted that there are some similarities and differences with respect to the segments that have been identified in the prior research. For example, the 'family togetherness tourists' in Park and Yoon's (2009) study appear to be similar to 'familyoriented tourists' that have been identified in Frochot's (2005) and Molera and Albaladejo's (2007) study. 'Want-it-all tourists' are similar to the segment identified in Devesa, Laguna and Palacios (2010) and Kastenholz et al.'s (1999) study. Some segments, such as 'souvenir seekers', seem to be specific segments that can be applied in South Korea. In addition, some rural tourists were not as interested in rural environment itself as in spending time with their family in a quiet environment.

Few studies investigate rural tourists in other countries. For example, Lee, Park, \& Yoon (2006) identified five segments of rural tourists in South Korea: 'passive tourists,' 'ruralEentric tourists,' 'want it all tourists,' 'souvenir seekers,' and 'novelty seekers.' Park \& Yoon 
(2009) identified four segments in South Korea: 'family-togetherness tourists,' 'passive tourists,' 'want it all tourists,' and 'seeking learning and excitement tourists'. The segments designated by previous studies differ in the extent to which the tourists are interested in the 'rural environment' itself. Some tourists, for instance, were not as interested in 'rural environments' as in spending time with their family in a quiet environment.

Regarding accommodations, the tourists' preferred accommodation type is linked to their preferred travel style (Weaver, 1991; Basala \& Klenosky, 2001). Tourists seeking familiarity prefer larger-scale resorts and chain hotels, while those seeking novelty prefer small and locally owned accommodations to learn more about the 'local culture' (Basala \& Klenosky, 2001). Likewise, rural tourists' accommodation preferences may vary according to their desire to experience the local culture. A variety of accommodations are available, ranging from self-catered lodging and bed \& breakfasts to corporate hotels or resorts in rural areas (Morrison, Pearce, et al., 1996; Morrison, et al., 1996; Oppermann, 1996). Through an empirical study of rural tourism in Spain, Albaladejo-Pina \& Diaz-Delfa (2005) identified different demands for accommodation: large establishments (large resorts with sports facilities); moderate accommodations (open country or mountain lodging rented directly from the owner); accommodations architecturally reflective of the area located near a town; traditional two- or three-bedroom houses; and former mill houses that rent individual rooms.

In South Korea, rural tourism has experienced rapid growth in recent years (Park and Yoon, Formatted: Font: Times New Roman 2009; Yoon, 2008). Large investments, primarily from the Korean government, have led to Font color: Text 1 
the appearance of a wide range of accommodations on the market; the number of units available for rural tourists was approximately 13,000 rooms in 4,400 rural houses in 2009 (Rural Development Administration, 2009). However, it is not clear what types of accommodations are preferable and how they should be promoted in South Korea. With a majority of previous studies on rural tourism limited to Europe, little is known regarding the benefits and accommodation preferences sought by Korean rural tourists. Without a deeper understanding of Korean rural tourists, it would be difficult to satisfy such tourists. This study is significant, as it provides tourism marketers with important information using a benefit market segmentation approach, profiling the characteristics of each segment by focusing on its accommodation preferences. By conducting a market segmentation analysis based on the benefits, this study offers useful information to international and domestic destination marketers who target Korean tourists.

In South Korea, rural tourism has a short history, but it is expanding rapidly due to strong support from the Korean government (Lee et al. 2006; Park \& Yoon, 2009). Because previous studies on rural tourism have been limited to Europe, little is known regarding the benefits and accommodation preferences sought by Korean rural tourists. Therefore, further studies are needed for an improved understanding of Korean rural tourists. By conducting a market segmentation analysis based on the benefits these tourists seek, we can provide useful information to international and domestic destination marketers who target Korean tourists.

\section{METHODOLOGY}




\section{Study site}

The numbers of rural holiday accommodation units and their guests have consistently and rapidly risen in Korea for the last decade. According to the -(Korea Tourism Organization, Ww. Visitkorea.or.kfNational Statistics (2011), - _been are-increased from 3,278 in 2005 to 4,468 in 2010 and. And the number of rural restaurants has nearly doubled are increased from 5,174 in 2005 to 9,043 in 2010. Over the last two decades, rural tourism has become a core economic activity for the majority of the rural areas in Korea. However, only in recent decades, especially in the 2000s, has-this type of tourism (including on organic farms) has experienced rapid and continuous growth (Choo \&and Jamal, 2009). The main driver of rural tourism in South Korea has been the development of various institutionally supported projects in different areas and regions. In

2009, the Rural Development Administration (2009) estimated the number of accommodation units available for tourist accommodations was approximately 13,000 rooms in 4,400 rural houses.

The typology of accommodations in the Korean rural tourism market is highly varied (Choo \&and Jamal, 2009; Lee, Park, \&and Yoon, 2006). Accommodations are available in hostels, campsites, rented houses, and 'rural houses' and represent the main rural tourism experiences in Korea since the early 2000s. Rural houses exhibit several characteristics that result from the philosophy inherent in rural tourism and distinguish them from other types of lodging. They are located within rural environments; they offer a limited number of rooms and beds for guests; they are equipped with basic amenities; and they are architecturally consistent with the style of the surrounding area.

\section{Data collection}


Data were collected from rural tourists who visited rural tourism villages in Korea. These villages, funded by the RTTV and the GREV programs, were selected as a lens through which to examine the general behavior of rural visitors. To avoid site-specific bias regarding rural tourist locations and capacities, a random sample of visitors (18 years and older) in 23 rural tourism villages that were comparatively well developed were selected using a stratified sampling method. Survey questionnaires were distributed to survey sites within the threemonth period from June to August 2010, and visitors who had stayed in the village (survey site) for at least one night were invited to complete a questionnaire. The researchers then visited and collected survey questionnaires from all of the villages. The data were collected using a four-page self-administered questionnaire designed to gather information on the general benefits that motivated visitors' travel and travel behavior. A total of 500 visitors who had already stayed for one night or more were randomly selected and surveyed. Excluding $\underline{58}$ among 500 questionnaires (54 incomplete questionnaires and 2 questionnaires with outlier test and 2 not nested cases in the process of hierarchical cluster analyses), 442 valid questionnaires were used for the data factor, cluster, and multinomial logit analysis. In this study, the questionnaire contained questions for evaluating visitors' behaviors, demographics, attitudes, and benefits sought. The behavioral and demographic questions served largely classificatory and profiling purposes. The variables of interest with respect to both of these purposes included the preferred seasons for rural visitation and the preferred types of accommodations. These variables were assessed using closed-ended questions, depending on nature of the variables.

\section{Measurement and Data analysis}

The questionnaire was developed to measure the benefits that the tourists sought based on a comprehensive review of the tourists' segmentations for natural and cultural tourism 
(Formica \&and Uysal, 1998; Johns \&and Gyimothy, 2002) and rural tourism (Frochot, 2005;

Kastenholz, Davis, \&and Paul, 1999; Molera \&and Albaladejo, 2007; Park \&and Yoon, 2009).

The composition of the questionnaire included an awareness of the significant benefit sought for 22 six-dimensional questions. To ensure content validity, numerous interviews with rural tourists and providers of tourist lodging in the countryside were conducted to identify major dimensions of importance to tourists in the countryside. A 5-point Likert-type scale was used to assess all of the variables, ranging from (1) = "strongly disagree" to (5) = "strongly agree."

For the accommodation preferences measurement, rural accommodations in the study are Formatted: Indent: Left $0.5 \mathrm{ch}$, First line: $0 \mathrm{ch}$ considered as farm stay, hostel, inn, hotel/condominium, forest lodge, and camping. This is similar to the previous studies (Albacete-Sáez, Fuentes-Fuentes, and Lloréns-Montes, 2007; Albaladejo-Pina and Díaz-Delfa, 2009). And type of building are also similar to the previous studies (Albaladejo-Pina and Díaz-Delfa, 2005, 2009) and types of meal service and room types are more detailed rather than the previous studies (Albaladejo-Pina and Díaz-Delfa, 2005, 2009).

Basic tests were performed to determine the characteristics for each variable by using statistical techniques. There were 56-2 outliers among the respondents, which were removed. We calculated a normal distribution of variables, extreme value (outlier), and linearity to analyze errors in the collected data. As a result, normal distributions of variables were achieved in some degree based on skewness, kurtosis, and Cook’s distance.

In the process of hierarchical cluster analyses, two cases were not nested until the final stage of the clustering. Therefore, this case was eliminated, and 442 cases were analyzed. In addition, when the correlation of variables was linear under Pearson's correlation, the variables formed a certain degree of correlation to apply to statistical techniques.

The data were analyzed in three stages. First, factor analysis was used to identify the underlying motivation dimensions. Principal component analysis (PCA) with varimax 
rotation was used as an estimation method of factor analysis to identify the underlying benefit dimensions. This study employed the criteria suggested by Hair, Black, Babin, \&and Tatham (2006, p.122, 129). Afterwards, the factor scores for each respondent were saved and used in stage 2 for clustering benefits-sought segments. A reliability $\alpha$ (Cronbach's $\alpha$ ) was computed to check the internal consistency of items within each dimension.

Second, the analysis clustered individuals such that those within each cluster were more similar to each other than to those in other clusters to maintain homogeneity within the clusters and heterogeneity between the clusters. Hierarchy cluster analysis was used to identify the number of clusters, and an agglomeration schedule was prepared based on that cluster analysis. Then, $K$-means cluster analysis was used to classify the samples according to the travel experience parameters that best distinguished them. When using $K$-means analysis, we used the means of the cluster as the value obtained from the initial clustering value through hierarchical clustering analysis. Specifically, the $K$-means cluster method, commonly used in tourist segmentation research, was implemented (e.g., Cha et al., 1995; Formica \&and Uysal, 1998; Keng au \&and Cheung, Lee, 1999; Madrigal \&and Kahle, 1994). Discriminant analysis was used to indicate which of the benefit items caused differences and to assess the accuracy of membership segment classification.

Finally, multinomial logit analysis was employed to identify the characteristics of tourists most likely to prefer each type of benefit segment. Due to its ease and quick estimation of parameters, the multinomial logit analysis has been used in many empirical studies of choice in tourism (Pina \&and Delfa, 2005, 2009; Chen \&and Hsu, 1999; Haartsen, Groote, \&and Heigen, 2003; Molera \&and Albaladejo, 2007; Seddighi \&and Theocharous, 2002; Luzar, Diagne, Ecgan, and Assane, Gan, \&-Henning, 1998).; Molera \& Albaladejo, 2007).-It is a form of regression that describes with dummy variables the relationship between categorical variables with two (binomial) or more (multinomial) categories and one or more explanatory 
variables (which may be continuous or discrete).

\section{DATA ANALYSIS and RESULTS}

\section{Sample profile}

In Table 1, there were 223 female respondents (50.5\%) and 219 male respondents (49.5\%). The respondents fell in the below-39 (55.6\%) and 41-59 (39.0\%) age groups and had at least a university degree (63.6\%); 25.3\% were white-collar workers, and 18.1\% were professionals. Almost half (47.7\%) of the respondents were between US\$15,001 and US\$45,000. Few respondents (9.3\%) earned less than US $\$ 75,000$, while only $13.0 \%$ earned less than US $\$ 15,000$. For the life cycle of respondents, almost one quarter (26.7\%) of the respondents have children in elementary school. More than half (56.3\%) of the respondents live in an apartment home and have rural residential experiences.

\section{Table 1 about here}

\section{Principal component analysis}

Principal component analysis (PCA) was performed on the importance ratings of the 22 benefit-sought variables in the instrument development process. The first run produced a seven-factor solution with Eeigenvalues greater than 1, accounting for $59.8 \%$ of the total variance. However, three variables with low factor loading (below 0.5) were observed. These variables were deleted from the analysis, and a new factor solution was obtained using Eeigenvalues greater than 1 and $\underline{V}$ zarimax rotation. Six factors were identified within $68.19 \%$ of the total variance. A Kaiser-Mayer-Olkin measure yielded 0.836. Factor loadings of all relevant variables in the rotated factor matrix were each clearly related to only one factor. 
Cronbach's $\alpha$ 's of for the six factors ranged from 0.71 to 0.86 . The resultant six factors represent specific dimensions of the benefits sought for participating in rural tourism; these are 'new experience,' 'escape,' 'rurality,' 'learning,' ‘socialization,' and 'educational time with family' (see Table 2).

\section{Table 2 about here}

\section{Segmenting rural tourists}

This study used a cluster analysis to categorize local people on the basis of the benefits of their tourism activities. After calculating the total average of each of the six benefits-sought factors using the factor analysis, we conducted a hierarchical cluster analysis using Euclidean distance, which is the square of the Ward style. This approach has been recommended to measure distance using Centroid method and Ward's method (Hair et al., 2006).

This procedure generated a four-cluster solution based on the relative increase of the agglomeration coefficient and the dendrogram. The clustering coefficient increased rapidly from four clusters (Stage 444) as 754.427 to three clusters (Stage 445) as 842.310. Based on this finding, this study determined that the number of clusters is four.

Hierarchical clustering also has a disadvantage because it is easily affected by variable sizes or outliers. In particular, this type of analysis constantly combines the initial cluster centers. This analysis can lead to artificial results. It is preferable to determine the final result through a non-hierarchical cluster analysis to remedy these shortcomings. Thus, this research determined each value of the first initial seed from the flocks obtained through the cluster analysis. In addition, we used $K$-means, which is non-hierarchical clustering. $K$-means 
clustering has characteristics that render it less sensitive to outliers; for example, the method measures the distance between objects, including improper factors (Hair et al., 2006).

The MANOVA tests also revealed that the six factors helped to differentiate the four rural tourism benefit clusters $(\mathrm{p}<0.01)$. The Scheffe tests indicateed that the differences between clusters were statistically significant, thus distinct clusters had been indeed identified. Finally each cluster was named as follows: ‘Learning \& \&and Socialization', _Simply Escape’, _Rural Experience \&and Education', and 'Educational Time with Family'. In cluster 1, the mean scores of 'Llearning \& $\underline{\text { and }}$ S socialization' were higher than other variables such that cluster 1 was designated 'Llearning \& \&and $\underline{S}$ socialization.' In cluster 2, the mean score of the variable

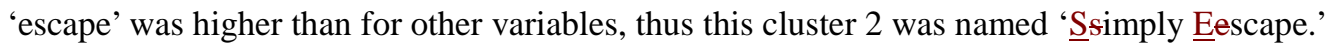
In cluster 3, the rural experiences and education had higher mean scores, such that this cluster was named 'Rfural experiences ㅌand Eeducation'. al time with family.Finally, in cluster 4, only educational time with family had a higher mean score than the other variables, thus this

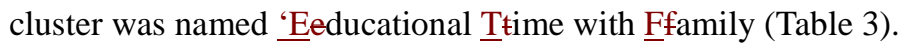

\section{Table 3 about here}

This research used discriminant analysis to investigate whether the clusters were classified properly. Leave-One-Out cross validation, one possible method of K-fold cross validation, can verify a sample after building a model with $\mathrm{N}-1$ observations. The hit ratio of the original data used in the discriminant analysis was $96.1 \%$ and had a cross-validation of $95.0 \%$. This cross-validation classification confirmed that the results of cluster analysis were valid.

\section{Table 4 about here}

Table 5 about here 


\section{Multinomial logit regression analysis}

Multinomial logit regression analyses were conducted to determine the variables affecting the type of benefit sought in rural tourism. The independent variables are socio-economic and tourism-related variables. The majority of these variables waswere initially selected from

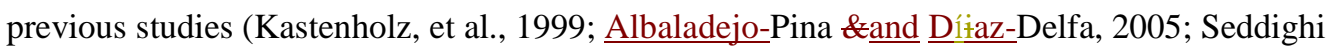
\&and Theocharous, 2002; Yagüe-Perales, 2002) and was built upon the basis of the survey results. Additional variables we added were the style of the room and building because there are some differences between Korean and Western countries. Using the SPSS 17 software and the data provided above, several mMultinomial lLogit models were developed. To confirm the overall fit of the model, this study inputted all of the variables and evaluated whether the change of -2 LL (-2 log likelihood) is significant. For logistic regression analysis, predictive accuracy is one technique for determining a model's fit. The predictive accuracy of this study was $62.1 \%$, a considerably higher discrimination compared to $50.9 \%$, the maximum chance criterion. Generally, classification accuracy greater than $25 \%$ for a standard implies that a model has discrimination. This research showed a discrimination value of $58.0 \%$. Therefore, the $65.5 \%$ predictive accuracy value was much higher accuracy than the $62.1 \%$ predictive accuracy value, which was much higher than the $58.0 \%$ value. This finding indicated that the model that was drawn had sufficient discrimination. In summary, the results showed that the estimated model demonstrated compatibility (Table 6).

This study established the four types of benefits sought in rural tourism that were then classified through the cluster analysis as dependent variables and the socio-demographic characteristics, tourism behavior, and accommodation preferences as independent variables. If independent variables are category types, dummy variables should be created for estimating models; furthermore, in this case, a reference group outside of the groups used for estimating models is necessary to avoid the problem of multicollinearity. Table 6 shows 
which items among the category type variables are reference items; it also displays the result of the logit regression analyses that indicated the reference items for which the coefficient values were not estimated. The reduced hypothesis is that all parameters of that effect are zero.

\section{Table 6 about here}

Several variables influence and determine the types of benefit sought. Of the variables that affect the types of benefits sought in rural tourism, age negatively affects the dependent variables in groups 1 (Learning ㄸand Socialization) and 4 (Educational Ttime with Ffamily). Hence, younger tourists are more likely to belong to groups 1 and group 4 rather than to group 2 (Simply Escape). Marital status also negatively affects the dependent variable group 4; thus, married tourists are more likely to belong to group 2 .

The experience of a rural residence is negatively affected by the dependent variable group 3 (Rural Experiences \& and Education), meaning that tourists who have the experience of a rural residence are more likely to belong to group 2 and group 3. Therefore, tourists who live in detached houses are more likely to belong to group 4 .

In the case of rural tourism experience during the year, group 4 has significant positive values. Tourists who have had a rural tourism experience in the past year are more likely to belong to group 4 than to group 2 . Travel expense is significant for group 1 and has positive values, such that tourists who incurred high travel expenses are more likely to belong to group 1 than to group 2 . The accommodation type is significant for group 1 and has negative values, such that tourists who preferred hotels/condominiums and forest lodges are more likely to belong to group 2 than to group 1 .

In the case of the preferred guest room style, group 3 has significant positive values, thus indicating that tourists who preferred Ondol-Bang (Korean-style) accommodations are more 
likely to belong to group 3 than to group 2. Favorite farm-stay building styles are significant for group 4 and have negative values; in other words, tourists who preferred Korean-style housing are more likely to be from group 2 than from group 4 .

Male tourists are significant for group 4 and have positive values, thus these tourists are more likely to belong to group 4 than to group 2. The mass media, internet, and recommendations from travel information channels are significant in group 4 and have positive values, thus tourists who preferred mass media, internet, and recommendations from travel information channel are more likely to belong to group 4 than to group 2 . Time to reach the travel destination is significant for group 1 and has positive values, thus tourists who took longer to reach their travel destination are more likely to reside in group 3 than in group 2. The farm size preference for two individuals is significant for group 3 and has negative values, thus tourists who prefer this size are more likely to belong to group 2 than to group 3. Breakfast as an included option in meal service is significant for group 1 and has negative values, thereby indicating that tourists who preferred a breakfast-type meal service are more likely to be in group 2 than in group 1 .

\section{DISCUSSION and CONCLUSION}

With the benefits of rural tourism for rural economies, rural tourism is becoming an important sector (Canoves et al. 2004; Fleisher \&and Flesenstein, 2000; Fleisher \&and Tchetchik, 2005; Fleischer \&and Pizam, 1997; Busby \&and Rendle, 2000;-Canoves et al. z004; Sharpley, 2002). In contrast to European countries, where rural tourism is in a 'mature' stage and has several decades' history (Canoves et al., 2004; Hjakager, 1996; Yague_-Perales, 2002; MacDonald \&and Jolliffe, 2003), there have been surprisingly few studies that focus on Asian countries, including South Korea, where rural tourism is in its 'beginning' stages 
(Lee et al. 2006; Park \&and Yoon, 2009). The need to have detailed information about the defining characteristics of the demand helps governments, tourism agencies and individual tourism operators to plan marketing and promotional campaigns or to make effective investment decisions for rural areas. Therefore, the goal of this study was to gain deeper insights into rural tourism in the Korean market. The sector of rural tourism in South Korea has been expanding, with the numbers of rural holiday accommodation units having rapidly risen for a last decade. Therefore, the current study investigates the benefits and accommodation preferences sought by Korean rural tourists. Through a benefits marketsegmentation approach, the characteristics of the segments were profiled.

The results of factor analysis identified six underlying dimensions of benefits sought in the Korean market; the factors include 'new experiences,' ‘escape,' 'rurality,' 'learning,' 'socialization,' and 'educational time with family'. These factors are similar to those identified by previous studies (Kastenholz et al. 1999; Park \& $\underline{a n d}$ Yoon, 2009; Molera \&and Albaladejo, 2007). Based on this result, this study performed a hierarchy cluster analysis to identify the number of clusters and a K-means cluster analysis to classify the sample. The results of the cluster analysis identified four clusters: 'Learning \& \&\& Socialization’ (19.7\%), ‘Simply Escape’ (31.1\%), 'Rural Experience \&and Education’ (30.9\%), and 'Educational Time with Family’ (18.3\%).

Segments were investigated further using a multinomial lॄogit analysis. Based on its results, the characteristics of each segment were profiled. The subsequent review of segments revealed that the first cluster of 'Learning \&\&\& Socialization' showed the highest demand among the six factors. This group is notably similar to the 'want-it-all' group identified in Kastenholz et al.’s (1999) study and in Park \&and Yoon’s (2009) study. The tourists in this group are white collar, married, professional, and relatively young. They spend more money than other groups and desire to experience something different from their everyday life. They 
are less likely to seek Western-style accommodations; rather, to satisfy their learning needs, they seek farm-stay or traditional Korean-style accommodations.

The second cluster, the 'Simply Escape' group, seeks 'familiar comforts'. Tourists in this group are relatively young and prefer to stay in a hotel or a vacation apartment rather than in traditional Korean-style accommodations. The benefits sought by this group are 'relaxation' and 'escape' from their everyday routine. Tourists consider rural tourism as one of their available options for relaxation and thus are less likely to be attracted to traditional Korean cultural experiences. Similar groups were identified in Molera \&and Albaladejo’s (2007) study as 'relaxation rural tourists' and in Frochot's (2007) study as 'relaxers'.

The third cluster, the 'Rural Experience \&and Education', seeks calm rural life experiences

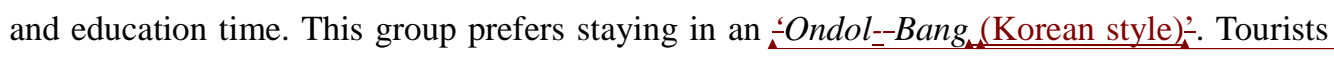
in this group travel long distances to visit rural areas. In the same context, 'independent ruralist' and 'traditional ruralist' were identified in the previous study (Frochot, 2005; Kastenholz's. 1999; Molera \&and Albaladejo_ 's, 2007).

The fourth cluster, the 'Educational Time with Family' group, especially values spending time with family and education for their children. In particular, they consider rural tourism as a good chance to 'teach' their children about the traditional Korean lifestyle and seek various activities and cultural experiences. They obtain information from the Internet and travel information centers. However, with regard to accommodation preferences, they prefer familiar-style rooms that have beds rather than traditional Korean-style rooms. In previous studies, Frochot’s (2005) 'gazers’ and Molera \&and Albaladejo’s (2007) 'family rural tourists’ seem to be similar to this group. In the Korean context, the 'family togetherness' group in Park \&and Yoon’s (2009) study are very close to this segment in terms of tourists’ priority about 'education' of children. This study supports Park \&and Yoon's (2009) argument that marketers should acknowledge the significance of 'education purpose' in understanding 
Korean rural tourists.”

Three conclusions can be drawn based on the findings of the current study. -First, this study supports the argument that rural tourists vary in terms of the benefits they seek when visiting rural areas. Some rural tourists seek rural experiences by participating in various activities, while others were more interested in relaxing than in experiencing rural environments. These benefits can be articulated along a continuum based on the tourist's level of orientation towards new experiences versus relaxation. Figure 1 summarizes the four

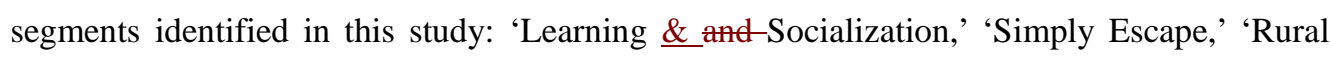
Experience \& and Education,' and 'Educational Time with Family'. At one extreme of this continuum are those who prefer to seek new experiences and to learn the culture of the place they visit, while on the other side are tourists who seek relaxation with urban comforts. The 'Llearning \& and $\underline{S} s$ socialization' group’ is oriented towards having new experiences, whereas the 'Ssimply Eescape' group' is highly oriented towards relaxation benefits. This study supports previous studies' findings that rural tourists are not homogenous; rather, they have a variety of demands ranging from 'experiencing rural cultures' to 'relaxation' (Barke, 2004; Molera \&and Albaladejo, 2007; Kastenholz et al. 1999; Frochot, 2005; Park \&and Yoon, 2009). 
The Benefits Sought by Korean

\section{Rural Tourists}

\begin{tabular}{|c|c|c|c|}
\hline $\begin{array}{l}\text { Learning Ori } \\
\text { (Seeking Ru }\end{array}$ & & & $\begin{array}{l}\text { axation } \\
\text { ented (Seeking }\end{array}$ \\
\hline xneriences & & & an Cornforts) \\
\hline $\begin{array}{c}\text { The`Learning } \\
\& \\
\text { Socialization' } \\
\text { group } \\
\cdot \text { Prefer } \\
\text { traditiona } \\
1 \text { Korean } \\
\text { style }\end{array}$ & $\begin{array}{l}\text { The 'Rural } \\
\text { Experiences \& } \\
\text { Education' } \\
\text { group } \\
\text { • Prefer } \\
\text { traditiona } \\
\text { 1 Korean } \\
\text { style }\end{array}$ & $\begin{array}{c}\text { The } \\
\text { ‘Educational } \\
\text { Time with } \\
\text { Family' group } \\
\text { - Have } \\
\text { previous } \\
\text { experienc } \\
\text { es in }\end{array}$ & $\begin{array}{l}\text { The 'Simply } \\
\text { Escape’ group } \\
\text { • Prefer } \\
\text { familiar } \\
\text { style } \\
\text { accommo } \\
\text { dation } \\
\text { (Hotel, }\end{array}$ \\
\hline
\end{tabular}

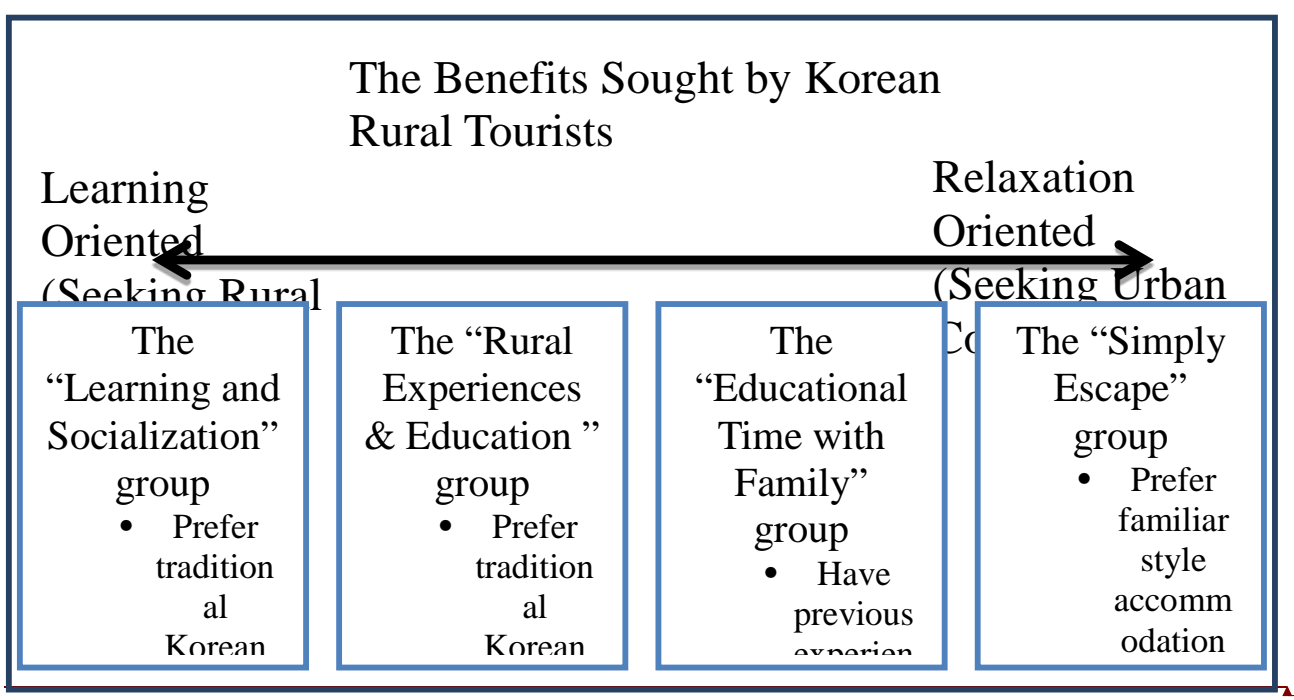

Figure 1. A continuum of benefits: relaxation-oriented and learning-oriented groups

Second, the current study suggests that rural tourism in South Korea should be promoted by emphasizing the ‘cultural elements’. All groups, except for the 'Śsimply Eescape’ group’, expressed their interest in experiencing rural cultures. This finding is clearly different from the findings in European countries. As Frochot (2005) noted, 'genuine interest in rural culture is in fact rather minor' (p.334). Rural tourists in European countries tend to visit rural
Formatted: Font color: Text 1

Formatted: Font color: Text 1 
areas to enjoy 'tranquility' and 'natural environments' (Oppermann, 1996; Canoves et al. 2005). However, the current study suggests that the situation is different in South Korea. Regarding this finding, Park \&and Yoon (2009) noted that “whereas rural tourists in European countries tend to be attracted by a peaceful atmosphere and nostalgia for old ways of life, ... Korean rural tourists are more likely to be interested in the role of agriculture and its associated culture,'- (p.106). In the South Korean context, rural tourists visit rural destinations not only for enjoying 'scenery' but also for 'learning' cultural and historical elements. In this case, it would be more effective if rural tourism in Korea is promoted by emphasizing 'cultural elements'. Rural destinations should identify their unique culture to be successful, and they should be supported by local communities (Sharpley, 2002). Various Moreover,-events or campaigns should be ean be-developed to enhance rural tourists' experiences (Panyik et al., 2011).

Third, the '-Ssimply Eescape' group' demonstrates that some of the rural tourists are not actually interested in 'traditional Korean-style' accommodations. This finding provides important information for the Korean government as well as rural tourism marketers. Some people choose to visit 'rural areas' for simply 'escaping' from their daily routines, thus they are not likely to be attracted by 'Korean-style’ (HanOk style) rooms. The Korean government has been renovating and constructing a considerable number of 'traditional Korean-style' accommodations throughout South Korea (Rural Development Administration, 2009). However, this study demonstrates that marketers should provide accommodations that provide urban comforts to rural tourists. The 'S $\underline{s i m p l y}$ Eescape' group' and the 'Eeducational Ttime with Ffamily' group' in this study, for example, showed great preference for accommodations that provide 'urban comforts'. Therefore, rural tourism marketers should ensure that various accommodation styles are available for tourists, including not only 'traditional Korean-style (HanOk)' accommodations but also 'hotel or resort style' 
accommodations to satisfy different segments in South Korea.

The limitations of this study should be acknowledged. Data collection was conducted using an on-site survey; thus, non-respondent bias and refusal bias could not be avoided. Nonetheless, this study's findings provide marketers with new insights into Korean rural tourists. Domestic and international destination marketers who are working for rural areas should acknowledge that distinct segments seek different benefits when visiting rural areas in Korea. Segmenting tourists based on the benefits sought can enable farmers operating farm stays and rural village leaders to identify effective marketing and business strategies. Marketers should pay more attention to the benefits sought by their target markets and meet the demand accordingly. By understanding the characteristics and accommodation preferences of their target markets, marketers can provide rural tourism products that meet their customers' needs.

\section{REFERENCE}

Albaladejo-Pina IP, Díiaz-Delfa, MT. 2005. Rural tourism demand by type of accommodation. Tourism Management 26(6): 951-959.

Albaladejo-Pina IP, Díaz-Delfa, MT. 2009. Tourist preferences for rural house stays: Evidence from discrete choice modeling in Spain. Tourism Management 30: 805-811

Albacete-Sáez CA, Fuentes-Fuentes MM, Lloréns-Montes FJ. 2007. Service quality

measurement in rural accommodation. Annals of Tourism Research 34(1): 45-65.

Barke M. 2004. Rural tourism in Spain. International Journal of Tourism Research 6(3): Formatt

Formatted: Font color: Text 1

$\underline{137-149 .}$

Basala SL, Klenosky DB. 2001. Travel-style preferences for visiting a novel destination: A conjoint investigation across the novelty-familiarity continuum, Journal of Travel Research 40(2): 172-182. 
Bowen JT. 1998. Market segmentation in hospitality research: no longer a sequential process. International Journal of Contemporary Hospitality Management 10(7): 289-296.

Busby G, Rendle S. 2000. The transition from tourism on farms to farm tourism. Tourism Management 21(6): 635-642.

Butler, R., Hall, M. (1998). Conclusion: The sustainability of tourism and recreation in rural areas. In Tourism and Recreation in Rural Areas, R. Butler, M. Hall and J. Jenkins, eds., pp. 249-258. Toronto: Wiley.

Canoves, G., Herrera, L., Villarino, M. (2005). Turismo rural en Espan a: Paisajes y usuarios, nuevos usos y nuevas visiones. Cuadernos de Turismo, 15, 63-76.

Canoves G, Villarino M, Priestly GK, Blanco A. 2004. Rural tourism in Spain: an analysis of recent evolution. Geoforum 35(6): 755-769.

Cha S, McCleary KW, Uysal M. 1995. Travel motivations of Japanese overseas travelers: a factor-cluster segmentation approach. Journal of Travel Research 34(1): 33-39.

Chen JS, Hsu CHC. 1999. The use of logit model to enhance market segmentation methodology. Journal of Hospitality \& Tourism Research 23(3): 268-283.

Choo H, Jamal T. 2009. Tourism on organic farms in South Korea: a new form of ecotourism? Journal of Sustainable Tourism 17(4): 431-454.

Devesa M, Laguna M, Palacios A. 2010. The role of motivation in visitor satisfaction: Empirical evidence in rural tourism. Tourism Management 31(4): 547-552.

Echtner CM. 1995. Entrepreneurial training in developing countries. Annals of Tourism Research 22(1): 119-134.

Fleischer A, Pizam A. 1997. Rural tourism in Israel. Tourism Management 18(6): 367-372

Fleischer A, Felsenstein D. 2000. Support for rural tourism: Does it make a difference? Annals of Tourism Research 27(4): 1007-1024.

Fleischer A, Tchetchik A. 2005. Does rural tourism benefit from agriculture? Tourism 
Management 26(4): 493-501.

Formica S, Uysal M. 1998. Market segmentation of an international cultural- historical event in Italy. Journal of Travel Research 36(4): 16-24.

Frochot I. 2005. A benefit segmentation of tourists in rural areas: a Scottish perspective, Tourism Management 26(3): 335-346.

Getz D, Carlsen J. 2000. Characteristics and goals of family and owner-operated businesses in the rural tourism and hospitality sectors. Tourism Management 21(6): 547-560.

Hjalager AM. 1996. Agricultural diversification into tourism; Evidence of a European community development programme. Tourism Management 17(2): 103-111.

Hair JH Jr, Black WC, Babin BJ, Tatham RL. 2006. Multivariate data analysis. Upper Saddle River, NJ: Prentice Hall.

Haartsen T, Groote P, Huigen P. 2003. Measuring age differentials in representations of rurality in The Netherlands. Journal of Rural Studies 19(2): 245-252.

Johns N, Gyimothy S. 2002. Market segmentation and the prediction of tourist behaviour: The case of Bornholm, Denmark. Journal of Travel Research 40(3): 316-327. Kastenholz E, Davis D, Paul G. 1999. Segmenting tourism in rural areas: The case of North and Central Portugal. Journal of Travel Research 37(4): 353-363.

Keng KA, Cheng JLL. 1999. Determining tourist role typologies: an exploratory study of Singapore vacationers. Journal of Travel Research 37(4): 382-390.

Lee M, Park DB, Yoon YS. 2006. A benefit segmentation of tourists in rural areas. Journal of Tourism Science 30(6): 219-240.

Lee CK, Lee YK, Bernhard BJ, Yoon YS. 2006. Segmenting casino gamblers by motivation: A cluster analysis of Korean gamblers. Tourism Management 27(5): 856-866.

Liu A. 2006. Tourism in rural areas: Kedah, Malaysia. Tourism Management 27(5): 878-889. Luzar EJ, Diagne A, Ecgan C, Henning BR. 1998. Profiling the nature-based tourist: A 
multinomial logit approach. Journal of Travel Research 37(1): 48-55.

MacDonald R, Jolliffe L. 2003. Cultural rural tourism: Evidence from Canada. Annals of Tourism Research 30(2): 307-322.

Madrigal R, Kahle LR. 1994. Predicting vacation activity preferences on the basis of value system segmentation. Journal of Travel Research 32(3): 22-28.

Molera L, Albaladejo PI. 2007. Profiling segments of tourists in rural areas of South-Eastern Spain. Tourism Management 28(3): 757-767.

Morrison AM, Braunlich CG, Cai LA, O’Leary JT. 1996. A Profile of the casino resort vacationer. Journal of Travel Research 35(2): 55-61.

Morrison AM, Pearce PL, Moscardo G, Nadkarni N, O’Leary JT. 1996. Specialist accommodation: Definition, markets served, and roles in tourism development, Journal of Travel Research 35 (1): 18-26.

National Statistics. 2011. Farm household income and expenditure survey. Deajeon, Korea: National Statistics. (http://kostat.go.kr).

Nilsson PA. 2002. Staying on farms: An ideological background. Annals of Tourism Research 29(1): 7-24.

Oppermann M. 1996. Rural tourism in Southern Germany. Annals of Tourism Research 23(1): 86-102.

Panyik E, Costa C, Ratz T. 2011. Implementing integrated rural tourism: An event-based approach. Tourism Management 32 (6): 1352-1363.

Park DB, Yoon YS. 2009. Segmentation by motivation in rural tourism: A Korean case study. Tourism Management 30(1): 99-108.

Roberts L, Hal, D. 2001. Rural tourism and recreation: principles to practice. Wallingford: CABI Publishing. 
Rural Development Administration. (2009). A fact-finding survey on rural tourism 2009. Suwon, Korea: Rural Development Administration.

Seddighi HR, Theocharous AL. 2002. A model of tourism destination choice: a theoretical and empirical analysis. Tourism Management 23(5): 475-487.

Sharpley R. 2002. Rural tourism and the challenge of tourism diversification: The case of

Cyprus. Tourism Management 23(3): 233-244.

Su B. 2011. Rural tourism in China. Tourism Management 32(6): 1438-1441.

Weaver DB. 1991. Alternative to mass Tourism in Dominica. Annals of Tourism Research 18(3): 414-432.

Wilson S, Fesenmaier DR, Fesenmaier J, Van Es JC. 2001. Factors for success in rural tourism development. Journal of Travel Research 40(2): 132-138.

Woodside AG, Jacobs LW. 1985. Step two in benefit segmentation: Learning the benefits realized by major travel markets. Journal of Travel Research 24(1): 7-13.

Yagüe-Perales RM. 2002. Rural tourism in Spain. Annals of Tourism Research 29(4): 1101$\underline{1110 .}$

Ying T, Zhou Y. 2007. Community, governments and external capitals in China's rural cultural tourism: A comparative study of two adjacent villages. Tourism Management 28(1): 96-107.

Yoon YS. 2008. Long-term plans for improving lodging service in Korea. Seoul: Korea $\underline{\text { Tourism Organization. }}$

Barke, M. (2004). Rural tourism in Spain. International Journal of Tourism Research, 6, 137149.

Basala, S., \& Klenosky, D. B. (2001). Travel-Style Preferences for Visiting a NovelDestination: A Conjoint Investigation across the Novelty-Familiarity Continumm, 
Journal of Travel Research,40, 172-182.

Bowen, J. T. (1998). Market segmentation in hospitality research: no longer a sequential process, 10/7, 289296.

Busby, G. \& Rendle, S. (2000). The transition from tourism on farms to farm tourism. Tourism Management, 21, 635-642.

Butler, R., \& Hall, M. (1998). Conclusion: The Sustainability of Tourism and Recreation in Rural Areas. In Tourism and Recreation in Rural Areas, R. Butler, M. Hall and J. Jenkins, eds., pp. 249 258. Toronto: Wiley.

Ganoves, G., Herrera, L., \& Villarino, M. (2005). Turismo ruralen Españ a: Paisajes y usuarios, nuevos usos y nuevas visiones. Cuadernos de Turismo, 15, 63-76.

Ganoves, G., Villarino, M., Priestly, G.K., and Blanco, A.(2004). Rural tourism in Spain: an analysis of recent evolution, Geoforum, 35, 755-769.

Cha, S., McCleary, M., \& Uysal, M. (1995). Travel motivations of Japanese overseas travelers: a factor-cluster segmentation approach. Journal of Travel Research, 33(2), 33-39.

Chen, J. S., \& Hsu, C. H. C. (1999). The use of logit model to enhance market segmentation methodololy. Journal of Hospitality \& Tourism Research, 23(3), 268-283.

Choo, H. \& Jamal, T. 2009. Tourism on organic farms in South Korea: a new form of ecotourism? Journal of Sustainable Tourism, 17(4), 131-154.

Đevesa, M., Laguna, M., Palacios, A. (2010). The role of motivation in visitor satisfaction: Empirical evidence in rural tourism. Tourism Management,31, 547-552.

Echter, C. M. 1995. Entrepreneurial Training in Developing Countries. Annals of Tourism Research, 22, 119-134.

Fleischer, A., \& Pizam, A. (1997). Rural tourism in Israel. Tourism Management, 18(6), 367- 
Fleischer, A., \& Felsenstein, D. (2000). Support for Rural Tourism: Does it Make a

Difference? Annals of Tourism Research 27:1007 1024.

Fleischer, A., Tchetchik, A. (2005). Does rural tourism benefit from agriculture? Tourism Management, 26, 493-501.

Formica, S., \& Uysal, M. (1998). Market segmentation of an international culturalhistoric event in Italy. Journal of Travel Research, 36(4), 16-24.

Frochot, I. (2005). A benefit segmentation of tourists in rural areas: a Scottish perspective, Tourism Management, 26, 335-346.

Getz, D. \& Carlsen, J. (2000). Characteristics and goals of family and owner-operated business in the rural tourism and hospitality sectors, Tourism Management, 21, 547 560.

Hjalager, A.M., (1996). Agricultural diversification into tourism; Evidence of a European Gommmenity development programme. Tourism Management 17, 103111.

Hair, J. H., Jr., Black, W. C., Babin, B. J., \& Tatham, R. L. (2006). Multivariate data analysis. Upper Saddle River, NJ: Prentice Hall.

Haartsen, T., Groote, P., \& Huigen, P. (2003). Measuring age differentials in representations of rurality in the Netherlands. Journal of Rural Studies, 19, 245-252.

Johns, N., \& Gyimothy, S. (2002). Market segmentation and the prediction of tourist behaviour: the case of Bornholm, Denmark. Journal of Travel Research, 40(3), 316 327.

Kastenholz, E., Davis, D., \& Paul, G. (1999). Segmenting tourism in rural areas: The case of North and Central Portugal. Journal of Travel Research, 37, $353-363$.

Kau, A. K., \& Lee, J. (1999). Determining tourist role typologies: an exploratory study of Singapore vacationers. Journal of Travel Research, 37(4), 382390. 
Lee, M., Park, D.-B., \& Yoon, Y. (2006). A benefit segmentation of tourists in rural areas. Journal of Tourism Science, 30(6), 219-240.

Lee, C-K, Lee, Y-K, Bernhard, B.J. \& Yoon, Y-S. (2006). Segmenting casin日 gamblers by motivation: A cluster analysis of Korean gamblers. Tourism Management, 27, 856-866.

Liu, A. (2006). Tourism in rural areas: Kedah, Malaysia, Tourism Management, $27878-889$. Luzar, E. J., Assane, D., Gan, C. E., \& Henning, B. R. (1998). Profiling the nature-based tourist: a Multinomial Logit approach. Journal of Travel Research, 37, 4855.

MacDonald, R. \& Jolliffe, L. (2003). Cultural Rural Tourism; Evidence from Eanada. Annals of Tourism Research, 30(2), 307-322.

Madrigal, R., \& Kahle, L. (1994). Predicting vacation activity preferences on the basis of value system segmentation. Journal of Travel Research, 13(3), 22-28.

Molera, L. \& Albaladejo, I. P. (2007). Profiling segments of tourists in rural areas of South-Eastern Spain. Tourism Management, 28, 757-767. Morrison, A. M., C. G. Braunlich, L. A. Cai, \& J. T. O'Leary (1996). A Profile of the CasinoResort Vacationer. Journal of Travel Research, 35 (2): 55-61. Morrison, A. M., P. L. Pearce, G. Moscardo, N. Nalkarni, \& J. T. O'Leary (1996). Specialist Accommodation: Definition, Markets Served, and Roles in Tourism Development, Journal of Travel Research, 35 (1): 1826.

Nilsson, P. A. (2002). Staying on farms—an ideological background. Annals of TourismResearch, 39(1), 724.

Oppermann, M. (1996). Rural tourism in southern Germany. Annals of Tourism Research, 
$23(1), 86-102$.

Panyik, E., Costa, C., \& Tamara, R. (2011). Implementing intetrated rural tourism: An eventbased approach, Tourism Management, 32 (6), 13521363.

Park, D.-B. \& Yoon, Y.-S. (2009). Segmentation by motivation in rural tourism: A Korean case study. Tourism Management, 30, 99-108.

Pina, I. P. A. \& Delfa, M. T. D. (2005). Rural tourism demand by type of accommodation. Tourism Management, 26, 951-959.

Roberts, L. \& Hall, D. (2001). Rural tourism and recreation: principles to practice. Wallingford: CABI Publishing.

Rural Development Administration. (2009). A fact-finding survey on rural tourism 2009. Suwon, Korea: Rural Development Administration.

Seddighi, H. R., \& Theocharous, A. L. (2002). A model of tourism destination choice: a theoretical and empirical andysis. Tourism Management, 23, $475-487$.

Sharpley, R. (2002). Rural tourism and the challenge of tourism diversification: The case of Eyprus. Tourism Management, 23, 233244.

St, B. (2011). Rural Tourism in China. Tourism Management, 32, 14381441.

Weaver, D.B. (1991). Alternative to Mass Tourism in Dominica, Annals of Tourism Research, $18(2), 414-432$.

Wilson, S., Fesenmaier, D.R., Fesenmaier, J., \& van Es, J. G. (2001). Factors for Success in Rural Tourism Development, Journal of Travel Research, 40, 132138.

Woodside, A.J., \& Jacobs, L.W. (1985). Step Two in Benefit Segmentation: Learning the Benefits realized by Major Travel Markets, Journal of Travel Research, 24(summer) 713.

Yagüe R. M. (2002). Rural tourism in Spain. Annals of Tourism Research, 29, 11011110. 
Ying, T., \& Zhou, Y. (2007). Community, governments and external capitals in China's rural eultural tourism: A comparative study of two adjacent villages, Tourism Management, 28, 96-107.

Yoon, Y. (2008). Long-term plans for improving lodging service in Korea. Seoul: Korea Tourism Organization. 
Table 1 Characteristic profile of the respondents ( $\mathrm{N}=442)$

\begin{tabular}{|c|c|c|c|c|}
\hline \multicolumn{3}{|c|}{ Frequency (\%) } & \multirow[t]{2}{*}{ Frequency (\%) } & \multirow[b]{2}{*}{ Formatted: Font color: Text 1} \\
\hline Gender & & Occupation & & \\
\hline Male & $219(49.5)$ & Professional & $80(18.1)$ & \\
\hline Female & $223(50.5)$ & Own business & $47(10.6)$ & \\
\hline Age & & Housewife & 79 (17.9) & \\
\hline $18-19$ & $13(2.9)$ & Blue-collar worker & $16(3.6)$ & \\
\hline $20-29$ & $84(19.0)$ & White-collar worker & $112(25.3)$ & \\
\hline 30-39 & 149 (33.7) & Student & $49(11.1)$ & \\
\hline $40-49$ & $124(28.1)$ & Sales clerk & $20(4.5)$ & \\
\hline $50-59$ & $48(10.9)$ & Others & $32(7.2)$ & \\
\hline More than 60 & $6(01.4)$ & Life cycle (multiple response) & & \\
\hline Annual Income (US\$) & & No children & $107(19.7)$ & \\
\hline Up to 15000 & $58(13.1)$ & Up to 5 years old & $60(11.0)$ & \\
\hline $15001-30000$ & 119 (26.9) & 6-7 years old & $58(10.7)$ & \\
\hline $30001-45000$ & $92(20.8)$ & Children in elementary school & 145 (26.7) & \\
\hline $45001-60000$ & $71(16.1)$ & Children in middle school & $52(9.6)$ & \\
\hline $60001-75000$ & $39(8.8)$ & Children in high school & $41(7.5)$ & \\
\hline More than 75000 & $41(9.3)$ & Children in university & $59(10.8)$ & \\
\hline Marital Status & & Children married & $22(4.0)$ & \\
\hline Married & $294(66.5)$ & Rural Residence Experience & & \\
\hline Single & $127(28.7)$ & Yes & $229(51.8)$ & \\
\hline Others & $8(1.8)$ & No & $204(46.2)$ & \\
\hline Educational Level & & Housing Form & & \\
\hline Below elementary-school graduate & $4(0.9)$ & Apartment & $249(56.3)$ & \\
\hline Middle-school graduate & $9(2.0)$ & Detached Housing & $83(18.8)$ & \\
\hline High-school graduate & $129(29.2)$ & Multiplex Housing & $82(18.6)$ & \\
\hline University graduate & $248(56.1)$ & Others & $10(2.3)$ & \\
\hline Graduate school & $33(7.5)$ & & & \\
\hline & & & & Formatted: Font color: Text 1 \\
\hline
\end{tabular}


Table 2 Factor analysis of benefit of Korean rural tourists

\begin{tabular}{|c|c|c|c|c|c|c|}
\hline Factor & $\begin{array}{l}\text { Factor } \\
\text { loading }\end{array}$ & $\begin{array}{c}\text { Eigen } \\
\text { value }\end{array}$ & $\begin{array}{c}\text { Variance } \\
\text { explained }\end{array}$ & $\begin{array}{c}\text { Cronbach's } \\
\alpha\end{array}$ & Mean $^{a}$ & \\
\hline Factor 1: New Experience & & 3.43 & 15.58 & 0.82 & 2.97 & Formatted: Font color: Text 1 \\
\hline Experience solitude & .78 & & & & 2.73 & \\
\hline Find thrills and excitement & .74 & & & & 2.78 & \\
\hline Indulge in luxury & .72 & & & & 2.46 & \\
\hline Indulge in reminiscence & .72 & & & & 2.91 & \\
\hline Experience the simple life & .70 & & & & 3.15 & \\
\hline Feel excitement & .48 & & & & 3.34 & \\
\hline \multirow[t]{2}{*}{ Gentle and elegant travel } & .43 & & & & 3.41 & \\
\hline & & 3.21 & 14.59 & 0.86 & 3.87 & Formatted: Font color: Text 1 \\
\hline Factor 2: Escape & .85 & & & & 4.02 & \\
\hline Get refreshed & .81 & & & & 3.94 & \\
\hline Escape from a busy job & .80 & & & & 3.85 & \\
\hline Relax from daily tension & .73 & & & & 3.70 & \\
\hline \multicolumn{7}{|l|}{ Enjoy a calm ambience } \\
\hline & & 2.35 & 10.69 & 0.84 & 3.62 & Formatted: Font color: Text 1 \\
\hline Factor 3: Rurality & .83 & & & & 3.51 & \\
\hline Enjoy the rural life & .81 & & & & 3.57 & \\
\hline Rural experience & .77 & & & & 3.75 & \\
\hline \multicolumn{7}{|l|}{ View rural scenery } \\
\hline Factor 4: Learning & & 2.19 & 9.93 & 0.76 & 3.65 & Formatted: Font color: Text 1 \\
\hline Learn new knowledge & .83 & & & & 3.56 & \\
\hline Unusual experiences & .74 & & & & 3.90 & \\
\hline Travel to historical heritage sites & .63 & & & & 3.50 & \\
\hline Factor 5: Socialization & & 1.93 & 8.77 & 0.71 & 3.27 & Formatted: Font color: Text 1 \\
\hline Inspire community consciousness & .78 & & & & 3.32 & \\
\hline Meet people with similar interests & .70 & & & & 3.08 & \\
\hline Enjoy famous place with others & .69 & & & & 3.39 & \\
\hline Factor 6: Educational time with family & & 1.90 & 8.63 & 0.82 & 3.83 & Formatted: Font color: Text 1 \\
\hline Educational time for their children & 88 & & & & 3.70 & \\
\hline Family togetherness & 83 & & & & 3.96 & \\
\hline Total variance extracted (\%) & \multicolumn{5}{|c|}{68.19} & Formatted: Font color: Text 1 \\
\hline \multicolumn{7}{|l|}{ Cronbach's $\alpha$ of all items } \\
\hline te: $1=$ & 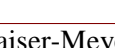 & , & - & & 0 & Formatted: Font color: Text 1 \\
\hline
\end{tabular}
square $=4199.041$. Bartlett's test of sphericity, $p<0.001$. 
Table 3 Benefit means among clusters

\begin{tabular}{lcccccc}
\hline Factor & $\begin{array}{c}\text { Cluster I } \\
\text { Learning \& } \\
\text { Socialization } \\
(\mathrm{n}=86 / 19.7 \%)\end{array}$ & $\begin{array}{c}\text { Cluster I } \\
\text { Simply } \\
\text { Escape } \\
(\mathrm{n}=136 / 31.1 \%)\end{array}$ & $\begin{array}{c}\text { Cluster III } \\
\text { Rural Experience } \\
\text { \& Education } \\
(\mathrm{n}=135 / 30.9 \%)\end{array}$ & $\begin{array}{c}\text { Cluster IV } \\
\text { Educational } \\
\text { Time with } \\
\text { Family } \\
(\mathrm{n}=80 / 18.3 \%)\end{array}$ & $\begin{array}{c}\text { Total } \\
\text { mean }\end{array}$ & F-value \\
\hline New experiences & $3.81 \mathrm{H}$ & $2.76 \mathrm{M}$ & $2.94 \mathrm{M}$ & $2.45 \mathrm{~L}$ & 2.96 & $88.08^{* * *}$ \\
Escape & $3.53 \mathrm{H}$ & $4.44 \mathrm{H}$ & $3.89 \mathrm{M}$ & $3.92 \mathrm{M}$ & 3.87 & $46.31^{* * *}$ \\
Rurality & $3.42 \mathrm{M}$ & $3.17 \mathrm{M}$ & $4.04 \mathrm{H}$ & $2.75 \mathrm{~L}$ & 3.61 & $157.01^{* * *}$ \\
$\begin{array}{l}\text { Learning } \\
\text { Socialization }\end{array}$ & $4.30 \mathrm{H}$ & $3.30 \mathrm{~L}$ & $3.78 \mathrm{M}$ & $3.37 \mathrm{~L}$ & 3.65 & $55.87^{* * *}$ \\
$\begin{array}{l}\text { Educational time } \\
\text { with family }\end{array}$ & $4.20 \mathrm{H}$ & $3.00 \mathrm{~L}$ & $3.09 \mathrm{~L}$ & $3.02 \mathrm{~L}$ & 3.26 & $82.24^{* * *}$ \\
\hline
\end{tabular}

Note: $1=$ strongly disagree, $5=$ strongly agree. ${ }^{* * *} p<0.001$.

Formatted: Font color: Text 1 
Table 4 Summary of discriminant analysis results

\begin{tabular}{|c|c|c|c|c|c|c|c|c|}
\hline Function & $\begin{array}{l}\text { Eigen } \\
\text { Value }\end{array}$ & $\begin{array}{c}\text { Percent of } \\
\text { Variance } \\
\text { Explained } \\
\text { by function }\end{array}$ & $\begin{array}{c}\text { Canonical } \\
\text { correlation }\end{array}$ & $\begin{array}{l}\text { Wilks’ } \\
\text { lambda }\end{array}$ & Chi-square & $\mathrm{df}$ & Sig. & \\
\hline 1 & 3.46 & 72.6 & 0.88 & 0.09 & 1050.76 & 18 & 0.000 & \multirow[t]{3}{*}{ Formatted: Font color: Text 1} \\
\hline 2 & 1.05 & 22.1 & 0.72 & $0 . \overline{39}$ & 406.64 & 10 & 0.000 & \\
\hline 3 & 0.25 & 5.3 & 0.45 & 0.80 & 97.05 & 4 & 0.000 & \\
\hline Discriminant loading & & & Function 1 & Function 2 & Function 3 & & & \\
\hline Novelty & & & 0.32 & 0.37 & 0.24 & & & \\
\hline Refreshment & & & 0.20 & -0.07 & 0.22 & & & \\
\hline Rurality & & & 0.33 & 0.60 & -0.62 & & & \\
\hline Learning & & & 0.13 & 0.14 & -0.08 & & & \\
\hline Socialization & & & 0.25 & 0.23 & 0.65 & & & \\
\hline $\begin{array}{c}\text { Educational time } \\
\text { with family }\end{array}$ & & & 0.77 & -0.62 & -0.06 & & & \\
\hline Note: $96.1 \%$ of or & grou & d cases $\mathrm{r}$ & ere correc & classifie & $95.0 \%$ of & & idated & Formatted: Font color: Text 1 \\
\hline
\end{tabular}


Table 5 Evaluation of cluster formation by classification results

\begin{tabular}{|c|c|c|c|c|c|c|}
\hline \multirow[t]{2}{*}{ Cluster case } & \multicolumn{5}{|c|}{ Predicted group membership } & \\
\hline & $\begin{array}{l}\text { Learning \& } \\
\text { Socialization }\end{array}$ & $\begin{array}{l}\text { Simply } \\
\text { escape }\end{array}$ & $\begin{array}{c}\text { Rural } \\
\text { experience \& } \\
\text { education } \\
\end{array}$ & $\begin{array}{l}\text { Educational } \\
\text { time with } \\
\text { family }\end{array}$ & Total & \\
\hline Learning \& & & & & & & Formatted: Font color: Text 1 \\
\hline Socialization & $80(93.0 \%)$ & $1(1.2 \%)$ & $3(3.5 \%)$ & $2(2.3 \%)$ & $86(100.0 \%)$ & \\
\hline Simply escape & $0(0.0 \%)$ & $134(98.5 \%)$ & $2(1.5 \%)$ & $0(0.0 \%)$ & 136(100.0\%) & \\
\hline $\begin{array}{l}\text { Rural experience \& } \\
\text { educational time with } \\
\text { family }\end{array}$ & $3(2.2 \%)$ & $2(1.5 \%)$ & $129(95.6 \%)$ & $1(0.7 \%)$ & $135(100.0 \%)$ & \\
\hline $\begin{array}{l}\text { Educational time with } \\
\text { family }\end{array}$ & $0(0.0 \%)$ & $0(0.0 \%)$ & $3(3.8 \%)$ & $77(75 \%)$ & $80(100.0 \%)$ & \\
\hline
\end{tabular}


Table 6 Summary of multinomial logit regression analysis

\begin{tabular}{|c|c|c|c|c|c|c|c|c|c|c|}
\hline & \multicolumn{2}{|c|}{$\begin{array}{l}\text { Likelihood ratio } \\
\text { tests }\end{array}$} & \multicolumn{2}{|c|}{$\begin{array}{l}\text { Learning \& } \\
\text { Socialization } \\
\text { (group 1) }\end{array}$} & \multirow{2}{*}{$\begin{array}{c}\text { Simply } \\
\text { Escape } \\
\text { (group 2) } \\
\text { (ref) }\end{array}$} & \multicolumn{2}{|c|}{$\begin{array}{l}\text { Rural experience and } \\
\text { Education } \\
\text { (group 3) }\end{array}$} & \multicolumn{2}{|c|}{$\begin{array}{l}\text { Educational time } \\
\text { with family } \\
\text { (group 4) }\end{array}$} & \\
\hline & $-2 \mathrm{LL}$ & $x^{2}$ & $\mathrm{~B}$ & Wald & & $\mathrm{B}$ & Wald & $\mathrm{B}$ & Wald & \\
\hline Intercept & 651.6 & - & -26.23 & 0.00 & 0 & -33.84 & 0.00 & -38.50 & 0.00 & Formatted: Font color: Text 1 \\
\hline $\begin{array}{l}\text { Gender } \\
\text { male }\end{array}$ & 655.0 & $3 . \overline{44}$ & 0.42 & 0.68 & $\begin{array}{l}0 \\
0\end{array}$ & 0.34 & 0.64 & 0.97 & $3.27 *$ & rormattea: ront color: I ext 1 \\
\hline female (ref) & & & $\begin{array}{c}0.42 \\
0\end{array}$ & 0 & 0 & 0 & 0 & 0 & 0 & \\
\hline Age & 660.1 & $8.49 * *$ & -0.58 & $3.59 *$ & 0 & -0.15 & 0.33 & -0.72 & $5.39 * *$ & \\
\hline Annual Income & 654.8 & 3.16 & -0.15 & 0.89 & 0 & -0.13 & 0.77 & 0.11 & 0.39 & \\
\hline Occupation & 676.6 & 25.03 & & & 0 & & & & & \\
\hline professional & & & 2.61 & $3.86^{* *}$ & 0 & 0.42 & 0.25 & 0.82 & 0.70 & \\
\hline own business & & & 3.00 & $4.84^{* *}$ & 0 & -0.35 & 0.15 & -0.77 & 0.50 & \\
\hline housewife & & & 2.85 & $4.31 * *$ & 0 & 0.17 & 0.04 & -0.16 & 0.03 & \\
\hline blue-collar worker & & & 1.98 & 1.47 & 0 & 0.30 & 0.06 & -1.17 & 0.58 & \\
\hline white-collar worker & & & 1.85 & 2.06 & 0 & 0.40 & 0.25 & -0.17 & 0.03 & \\
\hline student & & & 0.75 & 0.30 & 0 & -0.50 & 0.26 & -0.61 & 0.16 & \\
\hline sales clerk & & & 1.66 & 1.06 & 0 & 0.06 & 0.00 & -1.09 & 0.67 & \\
\hline others (ref) & & & 0 & 0 & 0 & 0 & .0 & 0 & .0 & \\
\hline Educational Level & 657.0 & 5.44 & 0.45 & 1.47 & 0 & 0.40 & 1.50 & -0.32 & 0.64 & \\
\hline Marital Status & 673.1 & $21.53^{* * *}$ & & & 0 & & & & & \\
\hline married & & & 13.61 & 0.00 & 0 & 1.19 & 0.65 & -1.60 & 1.12 & \\
\hline single & & & 11.90 & 0.00 & 0 & -0.47 & 0.09 & -5.35 & $8.18^{* * *}$ & \\
\hline others (ref) & & & 0 & 0 & 0 & 0 & 0. & 0 & 0. & \\
\hline Rural Residence Experience & 663.0 & $11.38^{* *}$ & & & 0 & & & & & \\
\hline $\begin{array}{l}\text { yes } \\
\text { no (ref) }\end{array}$ & & & $\begin{array}{c}0.48 \\
0\end{array}$ & $\begin{array}{c}1.11 \\
0\end{array}$ & $\begin{array}{l}0 \\
0\end{array}$ & $\begin{array}{c}-0.68 \\
0\end{array}$ & $2.77^{*}$ & 0.45 & 0.79 & \\
\hline Housing Form & 683.9 & $32.27 * * *$ & & & & & & & $\cdot$ & \\
\hline apartment & & & 15.82 & 0.00 & 0 & 15.98 & 0.00 & 2.90 & 2.52 & \\
\hline independent housing & & & 17.92 & 0.00 & 0 & 17.03 & 0.00 & 4.52 & $5.53 * *$ & \\
\hline multiplex housing & & & 14.94 & 0.00 & 0 & 15.02 & 0.00 & 2.82 & 2.35 & \\
\hline others (ref) & & & 0 & 0 & 0 & 0 & 0. & 0 & 0. & \\
\hline $\begin{array}{l}\text { Rural Tourism Experience For } \\
\text { Past Year }\end{array}$ & 661.5 & $9.91^{* *}$ & & & 0 & & & & & \\
\hline yes & & & -0.66 & 1.76 & 0 & 0.29 & 0.35 & 1.46 & $4.30^{* *}$ & \\
\hline no (ref) & & & 0 & 0 & 0 & 0 & 0. & 0 & . & \\
\hline Seasonal Preference & 662.2 & 10.56 & & & 0 & & & & & \\
\hline spring & & & -0.86 & 0.65 & 0 & 1.31 & 0.90 & 13.04 & 0.00 & \\
\hline summer & & & -0.88 & 0.73 & 0 & 1.23 & 0.83 & 13.74 & 0.00 & \\
\hline fall & & & -0.56 & 0.23 & 0 & 1.95 & 1.86 & 14.56 & 0.00 & \\
\hline winter (ref) & & & 0 & 0 & 0 & 0 & 0. & 0 & 0. & \\
\hline Accompany & 659.6 & 7.96 & & & & & & & & \\
\hline alone & & & -0.37 & 0.07 & 0 & -0.45 & 0.12 & -13.96 & 0.00 & \\
\hline family/relative & & & -0.64 & 1.32 & 0 & 0.13 & 0.07 & 0.09 & 0.03 & \\
\hline friend & & & -0.90 & 2.04 & 0 & -0.36 & 0.40 & -1.04 & 1.80 & \\
\hline group tour (ref) & & & 0 & 0 & 0 & 0 & 0. & 0 & 0. & \\
\hline Travel Information Channel & 657.0 & 5.44 & & & 0 & & & & & \\
\hline mass media & & & 0.02 & 0.00 & 0 & -1.23 & 0.00 & 9.27 & $74.32 * * *$ & \\
\hline internet & & & -0.59 & 0.00 & 0 & -1.41 & 0.00 & 8.94 & $144.42^{* * *}$ & \\
\hline recommendation & & & -0.61 & 0.00 & 0 & -1.58 & 0.00 & 9.25 & $139.87^{* * *}$ & \\
\hline information leaflet & & & -0.96 & 0.00 & 0 & -1.69 & 0.00 & 9.96 & . & \\
\hline travel agency (ref) & & & 0 & 0. & 0 & 0 & 0. & 0 & 0 & \\
\hline Travel Expense & 665.8 & $14.20^{* * *}$ & 0.02 & $8.81^{* * *}$ & 0 & 0.01 & 1.12 & 0.01 & 0.92 & \\
\hline $\begin{array}{l}\text { Rural Tourism Frequency For } \\
\text { One Year }\end{array}$ & 656.9 & 5.30 & -0.17 & 1.56 & 0 & -0.10 & 1.83 & 0.04 & 0.31 & \\
\hline $\begin{array}{l}\text { Required Time To Arrive at the } \\
\text { Travel Destination }\end{array}$ & 657.6 & 5.97 & 0.15 & 0.58 & 0 & 0.37 & $4.43^{* *}$ & 0.32 & 2.66 & \\
\hline Accommodation & 680.5 & $28.89 *$ & & & 0 & & & & & \\
\hline farm stay & & & -1.48 & 0.92 & 0 & 15.20 & 0.00 & 14.69 & 0.00 & \\
\hline hostel & & & -2.30 & 2.46 & 0 & 15.60 & 0.00 & 15.17 & 0.00 & \\
\hline inn & & & -2.61 & 2.45 & 0 & 14.80 & 0.00 & 15.64 & 0.00 & \\
\hline hotel/condominium & & & -2.98 & $3.81 *$ & 0 & 15.34 & 0.00 & 14.87 & 0.00 & \\
\hline forest lodge & & & -3.32 & $4.01^{* *}$ & 0 & 15.05 & 0.00 & 13.48 & 0.00 & \\
\hline friend/relative's house & & & -0.93 & 0.28 & 0 & 15.14 & 0.00 & 16.45 & 0.00 & \\
\hline camping (ref) & & & 0 & 0 & 0 & 0 & 0 & 0 & 0. & \\
\hline Guest Room Style & 658.1 & $6.53 *$ & -0.45 & 0.62 & 0 & 0.94 & $291 *$ & 0.38 & 0.36 & \\
\hline bedroom (Western style) (ref) & & & $\begin{array}{c}-0.45 \\
0\end{array}$ & $\begin{array}{c}0.02 \\
0\end{array}$ & 0 & $\begin{array}{c}0.94 \\
0\end{array}$ & 0 & $\begin{array}{c}0.08 \\
0\end{array}$ & $\begin{array}{c}0.36 \\
0 .\end{array}$ & \\
\hline $\begin{array}{l}\text { Preferred Farm-Stay Building } \\
\text { Style }\end{array}$ & 664.0 & $12.45^{*}$ & & & 0 & & & & & \\
\hline
\end{tabular}




\begin{tabular}{|c|c|c|c|c|c|c|c|c|c|c|}
\hline $\begin{array}{l}\text { Korean style house } \\
\text { Western style house } \\
\text { log house (ref) } \\
\text { Preferred Room Type } \\
\text { single } \\
\text { two person } \\
\text { three person } \\
\text { four person } \\
\text { more than five person (ref) } \\
\text { Preferred Meal Service } \\
\text { no service } \\
\text { breakfast } \\
\text { breakfast and dinner } \\
\text { all meals (ref) }\end{array}$ & 669.2 & 17.58 & $\begin{array}{c}-0.19 \\
-1.29 \\
0 \\
\\
-18.05 \\
-0.36 \\
-0.18 \\
0.09 \\
0 \\
\\
-0.44 \\
-1.39 \\
-0.19 \\
0 \\
\end{array}$ & $\begin{array}{c}0.15 \\
3.26^{*} \\
0 \\
\\
0.00 \\
0.17 \\
0.04 \\
0.03 \\
0 \\
0.43 \\
4.83^{* *} \\
0.08 \\
0 \\
\end{array}$ & $\begin{array}{l}0 \\
0 \\
0 \\
0 \\
0 \\
0 \\
0 \\
0 \\
0 \\
0 \\
0 \\
0 \\
0 \\
0 \\
\end{array}$ & $\begin{array}{c}0.23 \\
-0.32 \\
0 \\
\\
-16.07 \\
-2.76 \\
0.85 \\
0.54 \\
0 \\
\\
-0.35 \\
-0.57 \\
-0.50 \\
0 \\
\end{array}$ & $\begin{array}{c}0.28 \\
0.28 \\
0 \\
0.00 \\
4.57 * * \\
1.28 \\
1.78 \\
0 \\
\\
0.31 \\
1.04 \\
0.01 \\
0 \\
\end{array}$ & $\begin{array}{c}-1.03 \\
-0.38 \\
0 \\
\\
-4.13 \\
-1.59 \\
0.44 \\
0.48 \\
0 \\
\\
-0.10 \\
-0.24 \\
0.00 \\
0 \\
\end{array}$ & $\begin{array}{c}3.91^{* *} \\
0.22 \\
0 . \\
\\
0.00 \\
1.52 \\
0.25 \\
0.96 \\
0 . \\
\\
0.02 \\
0.15 \\
0.00 \\
0 \\
\end{array}$ & \\
\hline & $\begin{array}{l}\text { ood rat } \\
\text { ess-of- } \\
\text { R-Squ } \\
\text { ication }\end{array}$ & $\begin{array}{l}\text { st= } 300 \\
\text { earson } \\
\text { Cox anc } \\
\text { racy: } 62\end{array}$ & $\begin{array}{l}* * \text { (Interc } \\
2831.92 \\
\text { ell = } 0.5 \\
\text {, Press's }\end{array}$ & $\begin{array}{l}\text { only, }-2 \mathrm{~L} \\
=0.000) \\
\text { Nagelker } \\
=4.76^{* *}\end{array}$ & $\begin{array}{l}52.39 \\
\text { ance } \\
616\end{array}$ & $\frac{\text { al }-2 L L}{212(p}=$ & 598, $d f=$ & & & Formatted: Font color: Text 1 \\
\hline \multicolumn{10}{|c|}{ e difference in -2 log-likelihoods between th } & Formatted: Font color: Text 1 \\
\hline
\end{tabular}

